\title{
The phenology of winter rye in Poland: an analysis of long-term experimental data
}

\author{
Andrzej Blecharczyk $^{1}$ - Zuzanna Sawinska ${ }^{1}$ - Irena Malecka ${ }^{1}$ - Tim H. Sparks ${ }^{2,3}$. \\ Piotr Tryjanowski ${ }^{2}$
}

Received: 1 October 2015 /Revised: 16 December 2015 / Accepted: 21 December 2015 /Published online: 5 January 2016

(C) The Author(s) 2016. This article is published with open access at Springerlink.com

\begin{abstract}
The study of the phenology of crops, although quite popular, has limitations, mainly because of frequent changes to crop varieties and management practices. Here, we present data on the phenology and yield of winter rye in western Poland collected between 1957 and 2012 from a long-term field experiment. Data were examined for trends through time and compared to climatological factors using regression analysis. Both annual air temperature and precipitation increased during the study period, equivalent to $2{ }^{\circ} \mathrm{C}$ and $186 \mathrm{~mm}$, respectively, over the 52-year period for which met data were available. We detected significant delays in sowing date and recently in emergence, but significant advances were apparent in full flowering date equivalent to 4 days/decade. Yield and plant density experienced a step like change in 1986; yield increasing by ca. $70 \%$ and plant density increasing by ca. $50 \%$, almost coinciding with a similar change in annual mean temperature, but most likely caused by a changed seed rate and use of herbicides. Future climate change is expected to have a greater impact on this crop, but farmers may be able to adapt to these changes by modifying water regimes, using new machinery and sowing new rye varieties.
\end{abstract}

Piotr Tryjanowski

piotr.tryjanowski@gmail.com

1 Department of Agronomy, Poznań University of Life Sciences, Dojazd 11, 60-632 Poznań, Poland

2 Institute of Zoology, Poznań University of Life Sciences, Wojska Polskiego 71 C, 60-625 Poznań, Poland

3 Sigma \& Faculty of Engineering, Environment and Computing, Coventry University, Priory Street, Coventry CV1 5FB, UK
Keywords Agricultural practices · Crop phenology · Long-term experiment $\cdot$ Monoculture $\cdot$ Winter rye $\cdot$ Yield

\section{Introduction}

The observation and recording of phenological events has a long tradition. This tradition is closely related to the observation of weather and a dependency of mankind on the seasons. Phenology is especially important for understanding the development of cultivated plants (Chmielewski et al. 2004; Menzel et al. 2006a). Phenology was initially defined as "the study of the timing of recurring events, the causes of their timing with regard to biotic and abiotic forces, and the interrelation among phases of the same or different species" (Lieth 1974). More recent definitions, however, stress the important influence of the environment; Schwartz (1999) notes that "phenology includes the study of periodic events as influenced by the environment, especially temperature changes driven by weather and climate." Phenological dynamics are determined by complex interactions between genetic and environmental factors. Among the plant phenological phases, flowering time is the most frequently reported, because it is one of the simplest to record and one of the easiest to interpret (Chmielewski et al. 2004; Menzel et al. 2006a). Researchers have found air temperature to be a dominant factor controlling the timing of flowering and other phenological phases (Hunter and Lechowicz 1992; Galán et al. 2001).

The timing of when farmers begin to sow and harvest crops varies from year to year and is influenced by weather. Based on long-term observations of these events, practical recommendations have been provided to farmers in the form of phenological calendars (Chmielewski et al. 2004; Menzel et al. 2006a). Calendars have been compiled for many wild and cultivated plants (Chmielewski et al. 2004; Menzel et al. 
2006a), although recent trends in phenology may result in calendars now being inaccurate (Wittchen and Chmielewski 2005).

Among the crops most influenced by climate factors (Wittchen and Chmielewski 2005) is winter rye (Secale cereale L.). The Food and Agricultural Organization of the United Nations (FAO, www.faostat.fao.org) reported that world production of rye in the year 2011 was 12.9 million tons, of which three countries contributed $62 \%$ (Russian Federation $23 \%$, Poland $20 \%$, Germany $19 \%$ ). Rye grows well in much poorer soils than those required for most other cereal crops. Thus, it is an especially valuable crop in regions where the soil is sand or peat (Barnes and Putnam 1986; Schlegel 2006). Furthermore, rye will survive snow cover that would kill winter wheat (Prończuk et al. 2003).

The phenology of winter rye is not just important from a food production perspective but also with regard to pollen and allergens produced by the crop (Barnes and Putnam 1986). Within a region, the relative abundance of different pollenproducing plant species, their number of flowers and inflorescences, anther productivity, weather conditions, and abiotic factors all contribute to determine the pollen load in the air and thus its potentially allergenic effect (Myszkowska et al. 2011). In Poland, winter rye is considered to be a major allergen (Myszkowska et al. 2011; Kruczek and Puc 2012). Analysis of phenological data is thus also important to generate a regional pollen calendar and to predict the periods of increased pollen counts, which are important to know for the treatment of pollinosis (Kruczek and Puc 2012).

Making information available for farmers and medical services is sometimes difficult, especially for cultivated plants, because long-term series are distorted by changes in management regimes, sown varieties and soil nutrients (Chmielewski and Köhn 2000; Williams and Abberton 2004). Management by farmers is adapted not only to climate but also to local market prices and to technological advances (Chmielewski et al. 2004). Therefore, making long-term analyses of crop phenology is not trivial (Chmielewski and Köhn 2000; Williams and Abberton 2004).

Here, we present analyses on long-term data on winter rye in western Poland. We analyzed phenological changes over a 55-year period, the relationships between different phenophases, and the relationship of phenology to climate factors. Finally, we discuss the effects of changes in management practices, sometimes called farmer adaptations (Wittchen and Chmielewski 2005; Menzel et al. 2006a).

\section{Materials and methods}

Our study is based on a long-term experiment established in 1957 whose original aim was to demonstrate how fertilizers affected soil fertility and the yield of winter rye. The experiment was at the Brody Experimental Station $\left(52^{\circ} 26^{\prime}\right.$ $\mathrm{N}, 16^{\circ} 18^{\prime} \mathrm{E}, 92 \mathrm{~m}$ a.s.l.) of the Agronomy Department of Poznań University of Life Sciences, located $50 \mathrm{~km}$ west of Poznan in the Wielkopolska Region of western Poland. It was established as a randomized block design of four replicates on a podzolic soil. The soil texture was sandy loam with underlying loams. Prior to the experiment, the soil had a $\mathrm{pH}$ of about $6.0\left(\mathrm{pH}\right.$ in $\left.\mathrm{mol} \mathrm{KCl} \mathrm{dm}{ }^{-3}\right)$, a very high phosphorus content, average magnesium and potassium content, and contained about $7 \mathrm{~g} \mathrm{~kg}^{-1}$ of organic carbon. Fertilizer application has remained fairly constant using a 90:60:120 N/ $\mathrm{P}_{2} \mathrm{O}_{5} / \mathrm{K}_{2} \mathrm{O}$ compound. In 1986, herbicides were used for the first time. Harvesting methods have also changed over the years; until 1976 using a sheaf-binder, and later using three types of combine harvester: Hege 125 B (1977-1998), Wintersteiger Nurserymaster Elite (1999-2007), and Wintersteiger Classic (2008-). Three varieties have been grown: Wielkopolskie (until 1964), Smolickie (1964/1965-1971), Dańkowskie Złote (1971/1972-2012). Winter rye has been grown continuously since 1957 on the same plots. This is one of the oldest experiments in Poland, and one of only three designed in a similar way in Europe, based on a valid statistical design.

Phenological observations on rye in this experiment have been carried out for 55 years (1957/1958-2011/2012) using the BBCH scale (Lancashire et al. 1991). The BBCH scales are well known worldwide and are used for research, agronomy, and in phenology. In this study, we analyzed the following seven development stages of rye: sowing date $(\mathrm{BBCH} 00)$; emergence-leaf not completely unfolded (BBCH 10); stem elongation - start of the growing season in spring ( $\mathrm{BBCH} 30)$; heading - half of inflorescences emerged (BBCH 55); first flowering (BBCH 60); full flowering- $50 \%$ of anthers mature (BBCH 65); harvest (BBCH 89-92). All dates were converted to day of the year (DOY, $1=$ January 1 , etc.) prior to analysis, with autumn dates (e.g., sowing and emergence) as negative days of the year.

Mean annual winter rye yield data were available for the years 1958-2012. Established plant density in plants $/ \mathrm{m}^{2}$, average number of grains/ear and fertilizer applications $(\mathrm{kg} / \mathrm{ha})$ were available for the years 1972-2012. Further details of the study are discussed in detail in Blecharczyk (1999) and Szajdak et al. (2004). Mean monthly temperatures and monthly precipitation, collected according to WMO guidelines for the years 1961-2012, were obtained from the Brody Experimental Station meteorological station.

Standard regression and correlation methods were used to examine for trends over time, to compare phenological events with each other and with temperature and precipitation. Regression coefficients are presented \pm SE. Because three different varieties have been used in this experiment which may have influenced phenology and agronomic variables (e.g., preliminary analysis suggested that mean full flowering dates differed by 13 days between the three sown varieties), analysis 
has also been repeated using just the data from 1972 to 2012 (single variety in use) incorporating a dummy variable reflecting the seed rate/herbicide change in 1986. Consideration was also given to removing the effect of harvesting/combine type on crop yield. However, a one-way ANOVA testing harvesting method after elimination of seed rate/herbicide change revealed no significant difference on yield $\left(F_{3,50}=1.42, P=0.249\right)$. The influence of temperature and precipitation on phenology was investigated by stepwise regression with potential predictor variables being monthly mean temperature and monthly precipitation sum for the 3 months leading up to the mean date of the phase. The seed rate/herbicide change dummy variable was forced into these models to account for any effect of this change on phenology.

\section{Results}

The effect of the seed rate/herbicide change in 1986 was very evident on increased plant density $(433 \pm 10$ in $1986-2012$ vs. $287 \pm 9$ plants $/ \mathrm{m}^{2}$ in $\left.1958-1985\right)$ and yield $(5.35 \pm 0.16$ vs. $3.09 \pm 0.11 \mathrm{t} / \mathrm{ha}$, respectively). Mean values of phenological, agronomic, and meteorological information and their trends over time are summarized in Table 1. These data, uncorrected for any change in variety or management practice, revealed significant delays in sowing (by a total of 5 days over the 55 -year period), significant advances in shooting equivalent to 9 days and in full flowering equivalent to 20 days, and a significant delay in harvest equivalent to 8 days. There was a significant increase in yield, in plant density, and in number of grains/ear. Both annual temperature and precipitation had increased, equivalent to $2{ }^{\circ} \mathrm{C}$ and $186 \mathrm{~mm}$, respectively, over the 52-year period for which records exist. These patterns are shown in Fig. 1. Yield and plant density experienced a step-like change in 1986 likely primarily due to seed rate change and herbicide usage; yield increasing by ca. $70 \%$ and plant density increasing by ca. $50 \%$, almost coinciding with a steplike change in annual mean temperature after 1987 (the step change model for temperature was a better fit than a linear regression, $R^{2} 55.9 \%$ compared to $40.0 \%$ ).

Reanalysis of data just for the 1972-2012 period (one variety in use), incorporating a dummy variable to remove the effect of the seed rate/herbicide change, confirmed the delayed sowing date (2.2 days/decade) and advance in full flowering (4.0 days/decade). However, trends in shooting date, harvest date, yield, plant density, and grains/ear were no longer significant. Furthermore, there was also a significant delay in emergence date of 3.6 days/decade.

Of the 21 correlations between the seven phenological phases, eight were statistically significant (Table 2) and the bulk of these were with adjacent phases. The strongest correlations were between sowing and emergence dates, and between first and full flowering dates. There were significant negative correlations between sowing date and the two flowering phases, i.e., late sowing was associated with earlier flowering.

Table 1 Details of the phenological, agronomic, and climatological data of the experiment, together with a summary of linear regression of selected variables over time (regression on year)

\begin{tabular}{|c|c|c|c|c|c|c|c|c|c|c|c|c|}
\hline & \multicolumn{8}{|l|}{ 1958-2012 } & \multicolumn{4}{|c|}{$1972-2012$} \\
\hline & Mean & SD & Min & Max & $b$ & SE & $R^{2}$ & $P$ & $b$ & SE & $R^{2 \mathrm{a}}$ & $P^{\mathrm{a}}$ \\
\hline Sowing & -97 (Sep. 25) & 4 & -105 & -87 & 0.087 & 0.030 & 13.6 & 0.006 & 0.225 & 0.085 & 20.8 & 0.012 \\
\hline Emergence & -85 (Oct. 7) & 5 & -93 & -72 & 0.021 & 0.044 & 0.4 & 0.639 & 0.358 & 0.114 & 20.7 & 0.003 \\
\hline Shooting & 76 (Mar. 16) & 9 & 59 & 100 & -0.167 & 0.079 & 7.8 & 0.039 & 0.215 & 0.174 & 5.3 & 0.224 \\
\hline Heading & 108 (Apr. 18) & 8 & 93 & 123 & -0.127 & 0.069 & 6.0 & 0.071 & -0.104 & 0.176 & 17.8 & 0.556 \\
\hline First flower & 133 (May 13) & 5 & 118 & 149 & -0.064 & 0.046 & 3.5 & 0.169 & -0.152 & 0.103 & 33.2 & 0.267 \\
\hline Full flower & 149 (May 29) & 10 & 127 & 167 & -0.363 & 0.065 & 37.1 & $<0.001$ & -0.398 & 0.131 & 57.4 & 0.004 \\
\hline Harvest & 208 (Jul. 27) & 6 & 195 & 221 & 0.138 & 0.050 & 12.4 & 0.008 & 0.251 & 0.140 & 10.0 & 0.081 \\
\hline Yield (t/ha) & 4.20 & 1.36 & 1.55 & 6.57 & 0.064 & 0.008 & 56.9 & $<0.001$ & 0.007 & 0.019 & 62.5 & 0.720 \\
\hline Density (plants $/ \mathrm{m}^{2}$ ) & 383 & 85 & 242 & 551 & 4.39 & 0.89 & 38.3 & $<0.001$ & -1.27 & 1.12 & 69.0 & 0.264 \\
\hline Grains/ear & 34 & 6 & 17 & 52 & 0.163 & 0.080 & 9.6 & 0.049 & 0.260 & 0.142 & 11.2 & 0.074 \\
\hline Annual mean temperature $\left({ }^{\circ} \mathrm{C}\right)$ & 8.3 & 1.0 & 6.6 & 10.3 & 0.041 & 0.007 & 40.0 & $<0.001$ & & & & \\
\hline Annual total precipitation $\mathrm{mm}$ & 605 & 131 & 313 & 841 & 3.58 & 1.11 & 17.1 & 0.002 & & & & \\
\hline
\end{tabular}

$b$ represents the per year trend which is presented together with its standard error, \% variance accounted for $\left(R^{2}\right)$, and an indication of statistical significance $(P)$. Phenological and yield data for 1958-2012, other agronomic data for 1972-2012, and climatological data for 1961-2012

The regression models for 1972-2012 involve just a single variety in use and include a dummy variable (see text for details)

${ }^{a} R^{2}$ indicates the overall model, but $P$ just the significance of the trend through time 

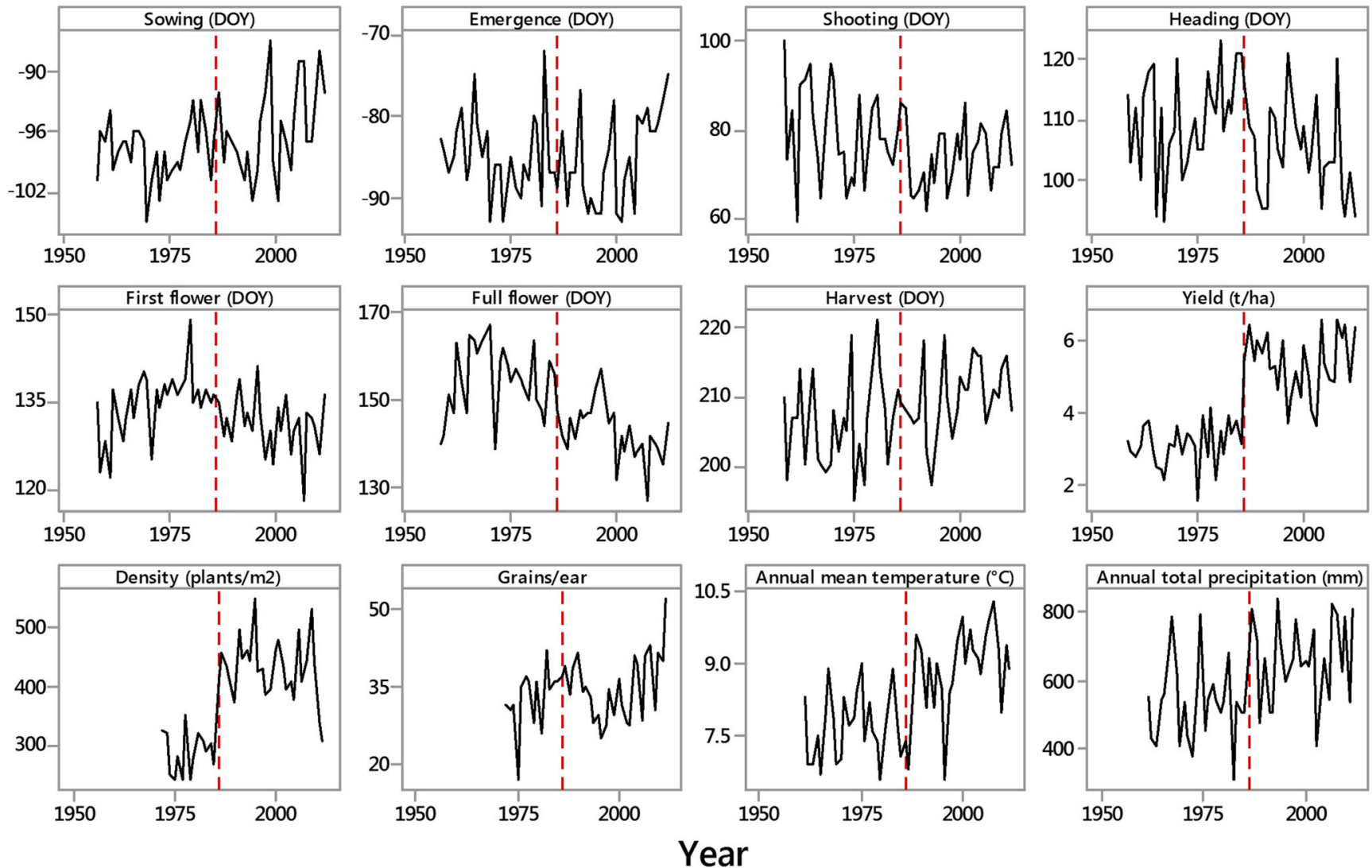

Fig. 1 Plots against year of the seven phenological measures in winter rye (day of year (DOY), 1 = January 1, etc.), yield, plant density, grains/ ear, annual mean temperature and annual total rainfall recorded at Brody, western Poland. The vertical line is at 1986, the year when sowing

techniques changed and herbicides were first used. Phenology and yield based on the years 1957/1958-2012, density and grains 1972-2012, and met data 1961-2012

Stepwise regression was performed to identify the influence of temperature and precipitation (in the 3 months leading up to the mean of that phase) on the seven winter rye phenophases. Analysis was restricted to the post-1972 single variety stage of the experiment and a dummy variable for change in seed rate/herbicide was forced into each regression. No significant effects of temperature or precipitation were detected on sowing date, emergence date, or harvest date. Negative temperature effects dominated the other phases with a $1{ }^{\circ} \mathrm{C}$ rise in temperature associated with a 1.7- to 3.8-day advance in phenology (Table 3). These values are consistent

with those found elsewhere (Estrella et al. 2007). Precipitation featured in only one of the models (first flower) and suggested earlier first flowering after wetter Mays. Models of flowering had notably larger values of $\%$ variance explained.

\section{Discussion}

In this study, we present analysis of observational records of seven phenophases of winter rye in western Poland over more than 50 years. In general, adjacent

Table 2 Pearson correlations $(r)$ between winter rye phenophases over 55 years in western Poland

\begin{tabular}{lllllll}
\hline & Sowing & Emergence & Shooting & Heading & First flower & Full flower \\
\hline Emergence & $0.644^{* * *}$ & & & & \\
Shooting & -0.109 & 0.076 & & & \\
Heading & -0.227 & -0.178 & $0.315^{*}$ & & \\
First flower & $-0.299^{*}$ & -0.017 & $0.303^{*}$ & $0.445^{* *}$ & & \\
Full flower & $-0.376^{* *}$ & -0.094 & 0.213 & $0.335^{*}$ & $0.671^{* * *}$ & \\
Harvest & 0.117 & 0.007 & 0.216 & 0.035 & 0.117 & -0.153 \\
\hline
\end{tabular}

Significant correlations: $* P<0.05, * * P<0.01, * * * P<0.001$ 
Table 3 Summary of stepwise regression analysis of winter rye phenophases in 1972-2012 on the mean temperature (T) and precipitation $(\mathrm{P})$ in the 3 months preceding the mean of the event

\begin{tabular}{llllllll}
\hline & \multicolumn{3}{l}{ Variables selected } & & Teffect & $R^{2}$ & $P$ value \\
\hline Shooting & Feb. T & Mar. T & & & & \\
& -0.95 & -1.64 & & -2.59 & 48.3 & $<0.001$ \\
Heading & Mar. T & & & & & & \\
& -1.65 & & & & -1.65 & 32.7 & $<0.001$ \\
First flower & Mar. T & Apr. T & May T & May P & & & \\
& -0.67 & -1.14 & -0.95 & -0.042 & -2.76 & 61.7 & $<0.001$ \\
Full flower & Apr. T & May T & & & & & \\
& -2.40 & -1.35 & & & -3.75 & 68.7 & $<0.001$ \\
\hline
\end{tabular}

The dummy variable for seed rate/herbicide change was forced into each model. No significant model was found for sowing date, emergence date or harvest date. Variables selected indicate the significant terms included in the model with coefficients below variable names. The column headed Teffect indicates the net effect in days of a $1{ }^{\circ} \mathrm{C}$ rise in temperature on that phase

phenophases were positively correlated, which is common in phenological traits (Roetzer et al. 2000; Ziello et al. 2012). This pattern was similar in both our whole time series and in just the last four decades when only one variety was grown (results not shown). However, only some of the phenophases were strongly related to climate events, mainly to temperature, which is in slight contrast to a previous study in Germany (Chmielewski et al. 2004). Obviously, part of the long-term change may be masked by other changes to management techniques (Chmielewski et al. 2004; Menzel et al. 2006b). It is especially interesting that the two phenophases more directly related to human activity (sowing and harvesting) were delayed over time, the former significantly, suggesting an adaptation by farmers, possibly to warmer late summers and autumns (Chmielewski et al. 2004; Menzel et al. 2006b). Obviously, adaptation not only involves the time of sowing and/or harvesting but also the use of different management techniques, and changes in technologies used to sow and harvest. Even changes in varieties have an influence (Howden et al. 2007); however, in our dataset, this effect was not obvious. In consequence, there have been marked longterm changes in crop density and yield, and in the use of artificial fertilizers (Sadowski and Krześlak 1995; Blecharczyk et al. 2004; Wittchen and Chmielewski 2005), although the latter was relatively stable in our study.

Even taking into account farmers' changes in timing of sowing, crop flowering remains strongly influenced by temperature (see also Estrella et al. 2007), and advanced flowering was noted for full flowering date but not first flowering date. This fact is of concern since it implies not only an earlier peak in the pollen season but a reduction in the interval between first and full flowering suggesting a greater pollen load over a shorter time span. This is important for constructing calendars for allergy sufferers (Myszkowska et al. 2011; Kruczek and Puc 2012; Ziello et al. 2012) and supports the view that these calendars should be changed over time (Ziello et al. 2012). A similar shortening of the flowering period was reported for native and exotic species by Bock et al. (2014). Temperature responses in rye were similar to, if somewhat smaller, that responses of native and exotic plant species recorded elsewhere in western Poland (Sparks et al. 2011).

The most favorable climate for the initial (autumn) growth and development of rye is likely to remain at 7.0-8.3 ${ }^{\circ} \mathrm{C}$ with precipitation of $48 \mathrm{~mm}$ per month (Dzieżyc et al. 1987). Dzieżyc et al. (1987) claim that the optimum precipitation between April and July for rye grown on light soil should total $251 \mathrm{~mm}$, distributed as follows: $34 \mathrm{~mm}$ in April, $60 \mathrm{~mm}$ in May, $84 \mathrm{~mm}$ in June, and $73 \mathrm{~mm}$ in July. Experimental yields of winter rye grown on suitable soils ranged from 3.19 to $5.27 \mathrm{t} \mathrm{ha}^{-1}$ (Budzyński et al. 2003). Four of the agronomic factors they analyzed significantly affected grain yield: sowing date, cultivar, NPK fertilizer, and weed control. Chemical weed control added an average $0.24 \mathrm{t} \mathrm{ha}^{-1}$, i.e., $6 \%$ of grain yield compared to rye fields grown without chemical treatments (Rola and Domaradzki 2001). A relatively low effectiveness of chemical weed control on winter rye fields confirms that rye is highly competitive toward weeds (Deryło and Szymankiewicz 1998). An exception to this is when rye is grown on the same land in two or more consecutive years, when it is at risk of being infested by common windgrass Apera spica-venti L. and noxious dicotyledonous weeds. Such limited rotations require application of herbicides, which can improve grain yield by about $15 \%$ (Budzyński 2001). In our experiment, the dramatic effect on yield of a change in seed rate and the application of herbicide almost coincided with a step-like change in temperature which has been more widely identified (Reid et al. 2015) but which was not significantly influential.

Our study clearly shows changing cultivation and phenology over the long-term, but strongly suggests that natural factors, especially temperature, continue to play a key role in understanding crop phenology, which is important from both an agronomic and medical perspective.

Acknowledgements The authors thank Dr. W. Waniorek and A. Knapczyk for assistance with obtaining some of the crop data, and the comments of two anonymous reviewers. 
Open Access This article is distributed under the terms of the Creative Commons Attribution 4.0 International License (http:// creativecommons.org/licenses/by/4.0/), which permits unrestricted use, distribution, and reproduction in any medium, provided you give appropriate credit to the original author(s) and the source, provide a link to the Creative Commons license, and indicate if changes were made.

\section{References}

Barnes JP, Putnam AR (1986) Evidence for allelopathy by residues and aqueous extracts of rye (Secale cereale L.). Weed Sci 34:384-390

Blecharczyk A (1999) Forty-years of fertilizing experiment in Brody with crops grown continuously and in crop rotation. Zesz Probl Post Nauk Rol 465:261-272 [in Polish]

Blecharczyk A, Małecka I, Pudełko J, Piechota T (2004) Effect of longterm fertilization and cropping systems on yield and macroelements content in winter rye. Ann UMCS Sec E Agricult 59:181-188 [in Polish]

Bock A, Sparks TH, Estrella N, Jee N, Casebow A, Schunk C, Leuchner M, Menzel A (2014) Changes in first flowering dates and flowering duration of 232 plant species on the island of Guernsey. Global Change Biol 20:3508-3519

Budzyński W (2001) Factors limiting rye yield. Pam Puł 128:25-37 [in Polish]

Budzyński W, Jankowski K, Szempliński W (2003) Cultivar-related and agronomic conditions of rye yielding on good rye soil suitability complex. EJPAU 6(1):\#04

Chmielewski F-M, Köhn W (2000) Impact of weather on yield components of winter rye over 30 years. Agricult Forest Meteorol 102: 253-261

Chmielewski F-M, Müller A, Bruns E (2004) Climate changes and trends in phenology of fruit trees and field crops in Germany, 1961-2000. Agricult Forest Meteorol 121:69-78

Deryło S, Szymankiewicz K (1998) Effect of tillage and cultivation on winter rye yield and weed infestation on light soil. Biul IHAR 205206:101-108 [in Polish]

Dzieżyc J, Nowak L, Panek K (1987) Decade indices of precipitation requirements by crops in Poland. Zesz Probl Post Nauk Rol 314: 35-48 [in Polish]

Estrella N, Sparks T, Menzel A (2007) Trends and temperature response in the phenology of crops in Germany. Global Change Biol 13: $1737-1747$

Galán C, García-Mozo H, Cariñanos P, Alcázar P, Domínguez-Vilches E (2001) The role of temperature in the onset of the Olea europaea L. pollen season in southwestern Spain. Int J Biometeorol 45:8-12

Howden SM, Soussana J-F, Tubiello FN, Chhetri N, Dunlop M, Meinke $\mathrm{H}$ (2007) Adapting agriculture to climate change. PNAS 104: 19691-19696

Hunter AF, Lechowicz MJ (1992) Predicting the timing of bud-burst in temperate trees. J Appl Ecol 29:597-604

Kruczek A, Puc M (2012) Phenology of flowering and pollen release of selected herbaceous plants in Szczecin and Gudowo (Western Pomerania) and the risk of pollen allergy. Acta Agrobot 65(4):49-60

Lancashire PD, Bleiholder H, van den Boom T, Langelüddeke P, Stauss R, Weber E, Witzen-Berger A (1991) A uniform decimal code for growth stages of crops and weeds. Ann Appl Biol 119:561-601
Lieth H (1974) Phenology and seasonality modeling. Springer-Verlag, Berlin-Heidelberg/New York

Menzel A, Von Vopelius J, Estrella N, Schleip C, Dose V (2006a) Farmers' annual activities are not tracking the speed of climate change. Clim Res 32:201-207

Menzel A, Sparks TH, Estrella N, Koch E, Aasa A, Ahas R, Alm-Kübler K, Bissolli P, Braslavská O, Briede A, Chmielewski F-M, Crepinsek Z, Curnel Y, Dahl Å, Defila C, Donnelly A, Filella Y, Jatczak K, Måge F, Mestre A, Nordli Ø, Peñuelas J, Pirinen P, Remišová V, Scheifinger H, Striz M, Susnik A, van Vliet AJH, Wielgolaski F-E, Zach S, Zust A (2006b) European phenological response to climate change matches the warming pattern. Global Change Biol 12:19691976

Myszkowska D, Jenner B, Stępalska D, Czarnobilska E (2011) The pollen season dynamics and the relationship among some season parameters (start, end, annual total, season phases) in Kraków, Poland, 1991-2008. Aerobiologia 27:229-238

Prończuk M, Madej L, Kolasińska I (2003) Research for resistance to Microdochium nivale among inbred lines of rye. Plant Breed Seed Sci 48:83-86

Reid PC, Hari RE, Beaugrand G, Livingstone DM, Marty C, Straile D, Barichivich J, Goberville E, Adrian R, Aono Y, Brown R, Foster J, Groisman P, Hélaouët P, Hsu H-H, Kirby R, Knight J, Kraberg A, Li J, Lo T-T, Myneni RB, North RP, Pounds JA, Sparks T, Stübi R, Tian Y, Wiltshire KH, Xiao D, Zhu Z (2015) Global impacts of the 1980s regime shift. Global Change Biol. doi:10.1111/gcb.13106

Roetzer T, Wittenzeller M, Haeckel H, Nekovar J (2000) Phenology in central Europe - differences and trends of spring phenophases in urban and rural areas. Int J Biometeorol 44:60-66

Rola H, Domaradzki K (2001) Occurrence, harmfulness and control of weeds in winter rye crop. Pam Puł 128:219-226 [in Polish]

Sadowski T, Krześlak S (1995) Performance of winter rye in different agroecological conditions. Fragm Agron 12(2):240-241

Schlegel R (2006) Rye (Secale cereale L.) - a younger crop plant with bright future. In: Sing RJ, Jauhar P (eds) Genetic resources, chromosome engineering, and crop improvement: cereals, volume II. CRC Press, Boca Raton, FL, USA, pp 365-394

Schwartz MD (1999) Advancing to full bloom: planning phenological research for the 21st century. Int J Biometeorol 42:113-118

Sparks TH, Górska-Zajączkowska M, Wójtowicz W, Tryjanowski P (2011) Phenological changes and reduced seasonal synchrony in western Poland. Int J Biometeorol 55:447-453

Szajdak L, Życzyńska-Bałoniak I, Meysner T, Blecharczyk A (2004) Bound amino acids in humic acids from arable cropping systems. J Plant Nutr Soil Sci 167:562-567

Williams TA, Abberton MT (2004) Earlier flowering between 1962 and 2002 in agricultural varieties of white clover. Oecologia 138:122126

Wittchen U, Chmielewski F-M (2005) Phytoclimate of winter rye stands. Meteorol Z 14:183-189

Ziello C, Sparks TH, Estrella N, Belmonte J, Bergmann KC, Bucher E, Brighetti MA, Damialis A, Detandt M, Galán C, Gehrig R, Grewling L, Gutiérrez Bustillo AM, Hallsdóttir M, KockhansBieda M-C, De Linares C, Myszkowska D, Pàldy A, Sánchez A, Smith M, Thibaudon M, Travaglini A, Uruska A, Valencia-Barrera RM, Vokou D, Wachter R, de Weger LA, Menzel A (2012) Changes to airborne pollen counts across Europe. PLoS ONE 7:e34076 